\title{
Antisense oligodeoxynucleotides targeting the serine/threonine kinase Pim-2 inhibited proliferation of DU-145 cells
}

\author{
Jin-ming DAI, Shu-qun ZHANG ${ }^{1}$, Wei ZHANG, Ru-xian LIN, Zong-zheng JI ${ }^{1}$, Sheng-qi WANG ${ }^{2}$ \\ Beijing Institute of Radiation Medicine, Beijing 100850, China; ' Department of Oncology, the Second Hospital of Xi'an Jiaotong University, \\ $X i$ 'an 710004, China
}

\section{Key words}

antisense oligodeoxynucleotide; Pim-2; cell proliferation; DU-145

\author{
${ }^{2}$ Correspondence to Prof Sheng-qi WANG. \\ Phn 86-10-6693-2211. \\ Fax 86-10-6821-4653. \\ E-mailsqwang@nic.bmi.ac.cn \\ Received 2004-06-14 \\ Accepted 2004-11-24 \\ doi: $10.1111 / \mathrm{j} .1745-7254.2005 .00050 . \mathrm{x}$
}

\begin{abstract}
Aim: To investigate the effect of antisense oligodeoxynucleotides (ASODN) targeting Pim-2 on cell proliferation of DU-145 cells. Methods: Three ASODN targeting Pim-2 were designed and synthesized. After transfection with ASODN, cell proliferation was analyzed using an MTS [3-(4,5-dimethylthiazol-2-yl)-5-(3carboxymethoxyphenyl)-2-(4-sulfophenyl)-2H-tetrazolium, inner salt] assay. In addition, Pim-2 mRNA, protein levels, and cell cycles were examined. Results: The ASODN designed and synthesized by our laboratory significantly reduced Pim-2 mRNA level and protein content in DU-145 cells. After transfection with ASODN for $48 \mathrm{~h}$, a marked reduction in cell viability was observed in DU-145 cells in a dose-dependent manner. No remarkable apoptosis occurred in cells treated with ASODN compared with control cells. However, it should be noted that $\mathrm{G}_{1}$ phase arrest was clearly observed in ASODN-treated cells. Conclusion: ASODN targeting Pim-2 resulted in a marked reduction in DU- 145 cell proliferation, and induction of $\mathrm{G}_{1}$ phase cell cycle arrest is one of the important mechanisms for ASODN to reduce cell growth. Moreover, antisense inhibition of Pim-2 expression provides a new promising therapy target for prostate cancer.
\end{abstract}

\section{Introduction}

Prostate cancer is the most frequent non-cutaneous malignancy and the second leading cause of cancer death among males in the western world. It has long been recognized that cancer arises as a result of somatic mutations; and a concept dramatically reinforced by the demonstration that a cellular "proto-oncogene" is mutationally involved in prostate cancer formation. To date a number of the genes associated with prostate cancer formation and progression have been identified, which are deregulated or abnormally overexpressed contributing to tumor formation. Recent technological developments have paved the way for the identification of the genes PRC17, Stat3, and Pim ${ }^{[1-5]}$. Identification of these genes provides a new target for prostate cancer therapy.

The Pim serine/threonine kinase family was first identified as a common proviral insertion site in T and B-cell lymphomas in mice ${ }^{[6]}$. To date, three family members have been identified: Pim-1, Pim-2, and Pim-3. These related enzymes show substantial homology, but differ in their tissue expres$\operatorname{sion}^{[7]}$. It is unknown to what extent the various family members differ in their biochemical effects. The Pim-2 gene encodes a cytoplasmic serine/thronine kinase whose expression is regulated by hematopoietic cytokines ${ }^{[8,9]}$. There are multiple isoforms of Pim-2 protein resulting from the use of the alternative translation start codon, $\mathrm{CTG}^{[10]}$. Among these isoforms, the short Pim-2 (34 kDa) form is the most active at enhancing survival of FDCP1 cells after cytokine withdrawal. The Pim-2 transgene induces lymphoid tumors, and exhibits potent synergy with c-myc ${ }^{[9]}$. Recent studies have indicated that Pim-2 kinase could phosphorylate the pro-apoptotic protein Bard on serine 112, and thus inhibit cell apoptosis ${ }^{[11]}$. Although the contribution of Pim-2 to cancer formation and progress is relatively unknown, Pim-2 has been recognized as a procongene, and procongenes are associated with many types of cancer formation.

At present, more and more patients are being diagnosed with early stage prostate cancer because of improvements in 
diagnostic techniques. Although surgery and chemotherapy are effective on patients with localized tumors, the prognosis of patients with advanced or metastatic tumors is not ideal. It is clear that novel treatment approaches to prostate cancer are urgently needed. It is now accepted that antisense oligodeoxynucleotides have sequences that are complementary to specific strands of RNA. Once delivered into a target cell, the oligodeoxynucleotides hybridise with its RNA complement and inhibit expression of the corresponding disease-relevant protein. More and more data demonstrate that antisense therapy for cancer is a very promising strategy. Consequently, the aim of our paper is to investigate whether inhibition of Pim-2 expression using antisense oligodeoxynucleotides can reduce proliferation of DU-145 cells.

\section{Materials and methods}

Antisense oligodeoxynucleotides The antisense sequences used in these experiments were designed using a computational neural network model ${ }^{[12]}$. BLAST confirmed that they were specific for the Pim-2 gene. Eicosomer ASODN were synthesized in our laboratory using an Applied Biosystems 391 DNA synthesizer and purified by OPC (Oligonucleotide Purification Cartrigde) (Perkin-Elmer, Foster City, CA, USA). Table 1 shows the sequence of ASODN.

Table 1. The sequence of antisense oligodeoxynucleotides (ASODN).

\begin{tabular}{ccc}
\hline No & Position & Sequence $\left(5^{\prime}-3^{\prime}\right)$ \\
\hline ASODN 1 & $4-23$ & CGCCGCGCGCTCGTGCCGAA \\
ASODN 2 & $123-142$ & CCTCGAACGCTTCCCGATCC \\
ASODN 3 & $344-363$ & TGGCCACCTGGAGTCGATCT
\end{tabular}

Cell line and culture Human prostate cancer cell lines, DU-145, were obtained from the Chinese Academy of Medical Sciences (Beijing, China). Cells were cultured in RPMI1640 medium (Invitrogen, San Diego, CA, USA) supplemented with $10 \%$ fetal bovine serum (GIBCO BRL, Grand Island, NY, USA), $100 \mathrm{kU} / \mathrm{L}$ benzylpenicillin and $100 \mathrm{mg} / \mathrm{L}$ streptomycin. All cultures were incubated at $37^{\circ} \mathrm{C}$ in a $5 \% \mathrm{CO}_{2}$ atmosphere.

Cell viability The effects of ASODN on cellular viability were determined using an MTS [3-(4,5-dimethylthiazol-2-yl)5-(3-carboxymethoxyphenyl)-2-(4-sulfophenyl)-2Htetrazolium, inner salt] assay. In brief, $3 \times 10^{3}$ cells were seeded in 96-well microtiter plate and allowed to attach overnight. Cells were then transfected with different concentrations
(0.1 $\mu \mathrm{mol} / \mathrm{L}, 0.2 \mu \mathrm{mol} / \mathrm{L}, 0.4 \mu \mathrm{mol} / \mathrm{L}, 0.8 \mu \mathrm{mol} / \mathrm{L})$ of ASODN. After $48 \mathrm{~h}$ of incubation, $20 \mathrm{~mL}$ of MTS (Sigma Chemical Company, St Louis, MO, USA) was added to each well. The 96-well microtiter plate was incubated for $2 \mathrm{~h}$ at $37^{\circ} \mathrm{C}$, and a $490 \mathrm{~nm}$ absorbance value was determined using an MR 600 Microplate reader (Wallac, Turku, Finland). Each assay was carried out in quadruplicate. Cellular proliferation inhibition rate is calculated as: $\left(A_{\text {control }}-A_{\text {sample }}\right) /\left(A_{\text {contro }}-A_{\text {blank }}\right) \times 100 \%$.

Lip-mediated transfection of antisense oligodeoxynucleotides Cells were plated in six-well plates at a density of $1 \times 10^{5}$ cells per well. Transfections were carried out after plating for $24 \mathrm{~h}$, when cells reached a confluence of (50-80)\%. Lipofectamine 2000 (Invitrogen) was used for transfection in this experiment and transfection was carried out according to the manufacturer's instructions. ASODN concentrations were selected as $0.1 \mu \mathrm{mol} / \mathrm{L}, 0.2 \mu \mathrm{mol} / \mathrm{L}$, $0.4 \mu \mathrm{mol} / \mathrm{L}, 0.8 \mu \mathrm{mol} / \mathrm{L}$, respectively. After transfection (incubation for $6 \mathrm{~h}$ at $37^{\circ} \mathrm{C}$ ), the cells were washed with phosphate-buffered saline (PBS) and incubated in fresh culture medium.

Reverse transcription-polymerase chain reaction (RTPCR) After transfection for $48 \mathrm{~h}$, total RNA was extracted using TRIzol (Invitrogen) by a single-step phenol extraction. Subsequent RT-PCR was carried out using a reverse transcription system (RT-PCR kit, Promega, Madison, WI, USA). In brief, first strand cDNA was synthesized using an Oligo $(\mathrm{dT})_{15}$ primer at $42^{\circ} \mathrm{C}$ for $30 \mathrm{~min}$. The PCR reaction for Pim-2 and $\beta$-actin was carried out in a single reaction of $20 \mathrm{~mL}$ volume. The latter served as a control following 32 cycles of denaturing at $95{ }^{\circ} \mathrm{C}$ for $45 \mathrm{~s}$, annealing at $55^{\circ} \mathrm{C}$ for $40 \mathrm{~s}$, and extending at $72^{\circ} \mathrm{C}$ for $40 \mathrm{~s}$. Under this reaction condition, the amplification showed linearity (data not shown). PCR products were run on a 3.0\% agarose gel and visualized using ethidium bromide staining, and the intensities were measured by scanning the gel with Gel Doc 1000 (Bio-Rad, Hercules, CA, USA). Inhibition of Pim-2 mRNA was calculated according to the following formula:

$$
\text { Inhibition percentage }(\%)=\left(\frac{1-A_{\text {sample }} \times A_{0 \text { control }}}{A_{\text {control }} \times A_{0 \text { sample }}}\right) \times 100
$$

where $A_{\text {sample }}$ is the intensity of Pim-2 PCR product in cells transfected with ASODN and lipofectamine, $A_{0 \text { sample }}$ is the intensity of Pim-2 PCR product in cells transfected with lipofectamine alone, $A_{\text {control }}$ is the intensity of $\beta$-actin product in cells transfected with ASODN and lipofectamine, and $A_{0 \text { control }}$ is the intensity of $\beta$-actin product in cells transfected with lipofectamine alone.

Western blot analysis After $72 \mathrm{~h}$ of transfection with 
ASODN, cells were lysed in RIPA buffer [10 mmol Tris-HCL (pH 7.4), 1\% deoxycholate, 1\% NP40, $150 \mathrm{mmol} \mathrm{NaCl}, 0.1 \%$ SDS, $0.2 \mathrm{mmol}$ phenylmethyl sulfonyl fluoride, $1 \mathrm{mg} / \mathrm{L}$ aprotinin and $1 \mathrm{mg} / \mathrm{L}$ leupeptin] for $30 \mathrm{~min}$ on ice. The lysates were centrifuged at $12000 \times g$ for $15 \mathrm{~min}$ to remove debris. Protein samples $(30 \mu \mathrm{g})$ were separated using $12 \%$ sodium dodecyl sulfate-polyacrylamide gel electrophoresis (SDSPAGE) gel and transferred onto hybond-polyvinylidene difluoride (PVDF) membranes (Schleicher \& Schuell Biosciences, Inc, Keene N H, USA). Pim-2 protein was identified using anti-Pim-2 primary and peroxidase-conjunct secondary antibody (Santa Cruz Biotechnology, Santa Cruz, CA, USA). Finally, the reactive band was visualized using an ECL-plus Detection Kit (Amersham Biosciences) and scanned by Gel Doc 1000 (Bio-Rad).

Cell cycle and apoptosis analysis Cell cycle assays were carried out as described previously ${ }^{[13]}$. In brief, cells were harvested after transfection with $0.4 \mu \mathrm{mol} / \mathrm{L}$ ASODN for 48 $\mathrm{h}$, and fixed with $70 \%$ ethanol at $-20^{\circ} \mathrm{C}$ overnight. Fixed cells were washed twice again with PBS, and stained with 50 $\mathrm{mg} / \mathrm{L}$ propidium iodide (PI) in the presence of RNase A. The stained cells were analyzed for DNA content by fluorescenceactivated cell sorting (FACS) in a FACScan (SOBR model, Becton-Dickinson, San Jose, CA, USA). Cell cycle fractions were quantified with CellQuest (Becton Dickinson), and apoptosis was estimated using the fraction of sub- $\mathrm{G}_{1}$ phase cells.

Statistics Data were expressed as mean \pm SD. Statistical analysis were carried out using Student's $t$-tests (two-tailed). $P<0.05$ indicates statistical significance.

\section{Results}

Effects of ASODN on Pim-2 expression After transfection of ASODN targeting Pim-2, semi-quantitative RT-PCR was used to determine the inhibitory effects on Pim-2 mRNA transcription. ASODN 1-3 examined in the present study exerted different inhibitory effects on mRNA transcription (Figure 1A). The Pim-2 transcription level was decreased by $64.5 \%, 56.8 \%$, and $55.2 \%(P<0.05)$ in DU-145 cells by ASODN1-3, respectively (Figure 1B). In addition, the Pim-2 protein amount was diminished by treatment with ASODN compared with the control (Figure 2).

Effects of ASODN on cell viability As shown in Figure 3, all of the ASODN targeting Pim-2 gene treatment significantly decreased cell viability, and the inhibition rate was dosedependent.

Effects of ASODN on DU-145 cell growth arrest and apoptosis Flow cytometry was used to quantify changes in
A

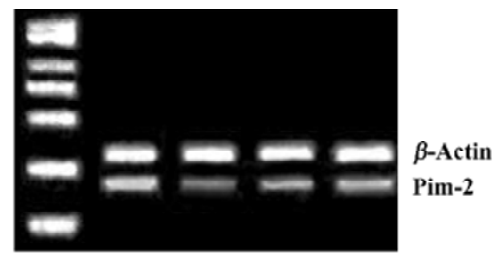

M CK ASODN1ASODN2ASODN3

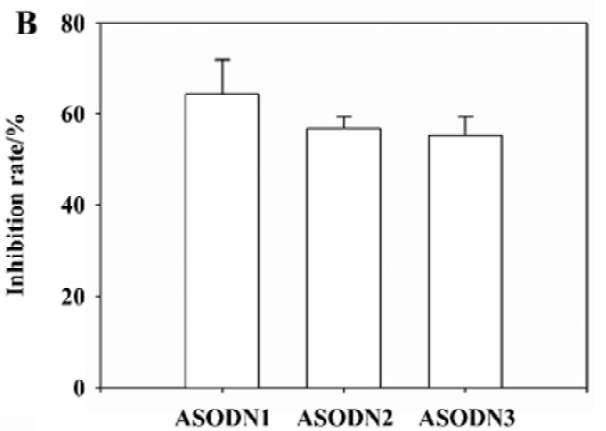

Figure 1. Effects of antisense oligodeoxynucleotides (ASODN) on mRNA level of Pim-2 in DU-145 cells. (A) Electrophoresis of reverse transcription-polymerase chain reaction products of the Pim-2 gene and $\beta$-actin gene in DU-145 cells transfected with ASODN1, 2 and 3. (B) Quantification of the data presented in (A). Data are expressed as mean $\pm \mathrm{SD}$ from four independent experiments. $P<0.05$ $v s$ the cells transfected with lipofectamine alone.
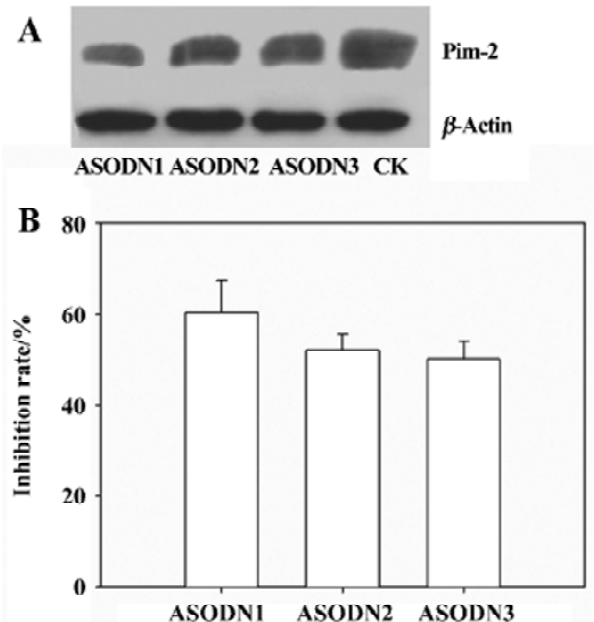

Figure 2. Inhibition of Pim-2 protein expression in DU-145 cells after transfection with antisense oligodeoxynucleotides (ASODN) 1, 2, and 3. (A) Cell extracts were separated using sodium dodecyl sulfate gel electrophoresis, transferred to a membrane and blotted with anti-Pim-2 goat polyclonal antibody. Anti- $\beta$-actin rabbit polyclonal antibodies were used as loading control. (B) Quantification of the data presented in (A). Data are expressed as mean \pm SD from four independent experiments. $P<0.05 v s$ the cells $(\mathrm{CK})$ transfected with lipofectamine alone. 


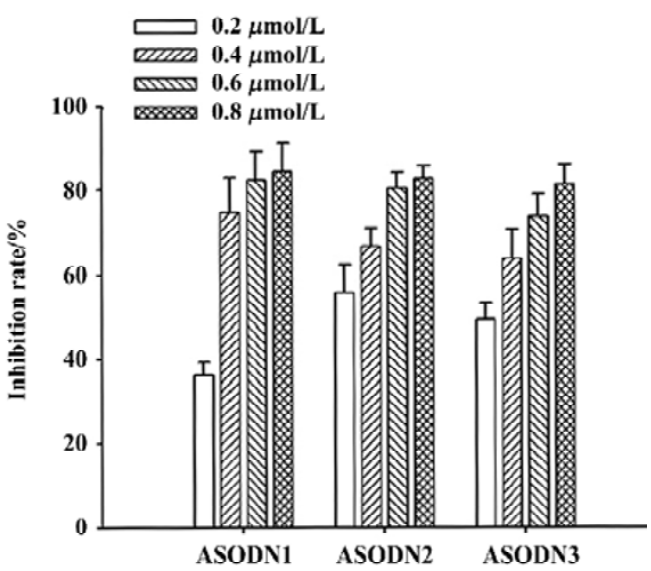

Figure 3. Effects of antisense oligodeoxynucleotides (ASODN) on the proliferation of DU-145 cells. Data are expressed as mean $\pm \mathrm{SD}$ from four independent experiments.

cell cycle and apoptosis $48 \mathrm{~h}$ after treatment with Pim-2 ASODN. All of the ASODN targeting Pim-2 increased the fraction of cells undergoing growth arrest at $\mathrm{G}_{0} / \mathrm{G}_{1}$ in DU-145 cells, and the inhibitory effect of ASODN1 was greater than the others (Table 2). It should be noted that no apparent apoptosis occurred in cells after treatment with any of the ASODN (Figure 4).

Table 2. Cell cycle distribution of DU-145 cells (\%) treated with antisense oligodeoxynucleotides (ASODN). ${ }^{b} P<0.05 v s$ the control group.

\begin{tabular}{lccrr}
\hline $\begin{array}{c}\text { Cell cycle } \\
\text { (phase) }\end{array}$ & ASODN1 & ASODN2 & ASODN3 & Control \\
\hline & & & & \\
$\mathrm{G}_{0} / \mathrm{G}_{1}$ & $71.68^{\mathrm{b}}$ & $69.78^{\mathrm{b}}$ & $65.72^{\mathrm{b}}$ & 51.76 \\
$\mathrm{G}_{2} / \mathrm{M}$ & 7.06 & 8.13 & 8.26 & 9.26 \\
$\mathrm{~S}$ & $21.26^{\mathrm{b}}$ & $22.09^{\mathrm{b}}$ & $26.02^{\mathrm{b}}$ & 38.98 \\
\hline
\end{tabular}

\section{Discussion}

The balance between cell death and cell proliferation determines cells survive or die. Although the detailed mechanism and function of Pim-2 in cells are still unknown, research suggests that Pim-2 acts as an important factor to mediate cell survival. Consequently, ASODN against Pim-2 are anticipated to restrain cell proliferation. In this experiment, three ASODN targeting Pim-2 were designed and synthesized by our laboratory. Results indicated that all three ASODN could specifically reduce the mRNA transcription and protein expression level of Pim-2 in DU-145 cells

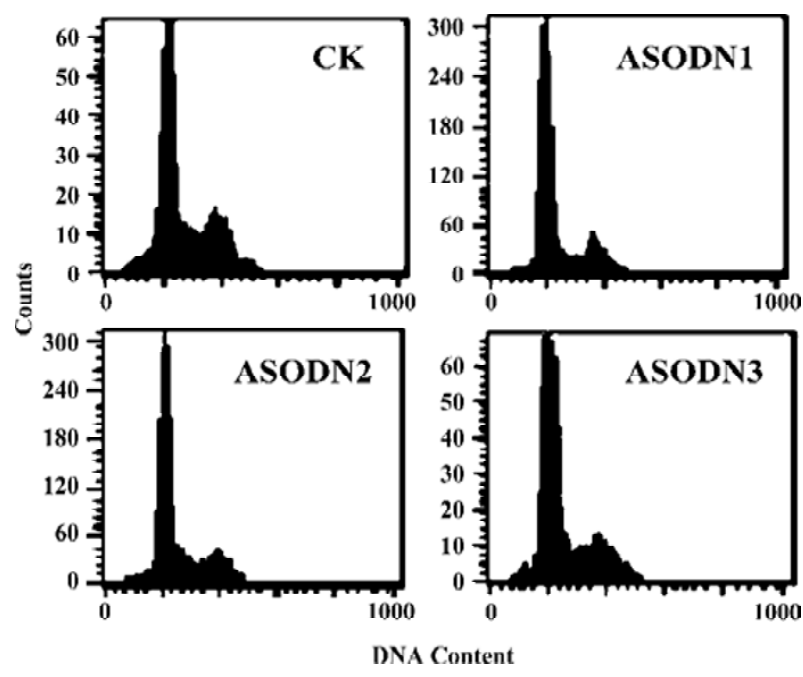

Figure 4. Analysis of cell apoptosis after transfection with antisense oligodeoxynucleotides (ASODN) in DU-145 cells. Cells transfected with lipofectamine alone were used as a control.

\section{(Figures 1,2).}

Prostate cancer is the most frequently diagnosed cancer in men. The incidence of prostate cancer rose in the late 1980s and early 1990s as a result of increased life expectancy, earlier and more accurate diagnosis, and increased public awareness of the disease. Nowadays, prostate cancer is believed to be the second leading cause of cancer related death in men. Thus, there is an urgent need to develop efficient therapy approaches to prostate cancer. Data presented here indicate that our ASODN could repress DU-145 cells growth to varying extents, and inhibitory effects were dose-dependent (Figure 3).

Despite extensive investigation, the physiological substrates of the Pim-2 kinase remain unknown. However, ASODN against Pim-2 induced marked $\mathrm{G}_{1}$ phase cell cycle arrest in DU-145 prostate cancer cells (Table 2). This result implies that a number of proteins that are associated with cell cycle control are substrates of Pim-2 kinase. Similarly, Pim-1, its homological gene, was found to phosphorylate the cell cycle inhibitor $\mathrm{p} 21 \mathrm{Cip} 1 / \mathrm{WAF} 1$ and abrogate $\mathrm{G}_{1}$ phase cell cycle arrest ${ }^{[14]}$. Taken together, these results offer evidence that the Pim serine/threonine kinase family show substantial homology, which can mediate the activity of a number of cell cycle related proteins. This experiment, implies that, in DU-145 cells, Pim-2 kinase is not the essential factor determining cell survival. In addition, abrogation of $\mathrm{G}_{1}$ phase cell cycle arrest by Pim-2 serine/threonine kinase may be an important mechanism for prostate cell proliferation.

Antisense therapeutics for cancer are, after decades of difficulties, finally close to fulfilling their promise in the clinic. 
Antisense compounds targeting certain genes, such as HER2, VEGF, IGF-IR, and protein kinase C, were reported to efficiently inhibit target gene expression ${ }^{[15-18]}$. Advances in defining molecular abnormalities in prostate cancer offer the hope of improving both the diagnosis and therapy of the disease. It is now well established that the progression of epithelial cells in the prostate from normal to dysplastic or adenomatous epithelium to carcinoma in situ and finally to invasive carcinoma is the result of the sequential accumulation of genetic abnormalities involving oncogenes and tumor suppressor genes. A number of genetic mutations are found in prostate cancer, including activating mutations of the Pim-2 oncogene and loss of the tumor suppressor gene $\mathrm{P}_{53}{ }^{[1-5]}$. In the present study, our antisense compounds could downregulate the expression of target mRNA level in vitro, as well as display certain antitumor activity. It is possible that antisense or other small molecule approaches to inhibit Pim-2 signaling may play a role in the treatment of patients with prostate cancer. In addition, a significant fraction of non-prostate tumors, including many colon, gastric, and testis carcinomas express elevated Pim-2 levels ${ }^{[19,20]}$. Whether or not antisense ODN targeting Pim-2 can also show antitumor activity against such neoplasm requires further study.

In summary, ASODN designed and synthesized by our laboratory against Pim-2 can efficiently suppress target gene expression and inhibit the growth of DU-145 cells, providing a new promising therapy target for prostate cancer.

\section{References}

1 Gonzalgo ML, Isaacs WB. Molecular pathways to prostate cancer. J Urol 2003; 170: 2444-52.

2 Maitland NJ, Stanbridge LJ, Dussupt V. Targeting gene therapy for prostate cancer. Curr Pharm Des 2004; 10: 531-55.

3 Hernandez I, Maddison LA, Wei Y, DeMayo F, Petras T, Li B, et al. Prostate-specific expression of p53 (R172L) differentially regulates $\mathrm{p} 21, \mathrm{Bax}$, and $\mathrm{mdm} 2$ to inhibit prostate cancer progression and prolong survival. Mol Cancer Res 2003; 1: 1036-47.

4 Pei L, Peng Y, Yang Y, Ling XB, Van Eyndhoven WG, Nguyen $\mathrm{KC}$, et al. PRC17, a novel oncogene encoding a Rab GTPase activating protein, is amplified in prostate cancer. Cancer Res 2002; 62: 5420-54.

5 Mora LB, Buttner R, Seigne J, Diaz J, Ahmad N, Garica R, et al. Constitutive activation of stats in human prostate tumors and cell lines: direct inhibition of Stat3 signalling induces apoptosis of prostate cancer cells. Cancer Res 2002; 62: 6659-66.

6 Cuypers HT, Selten G, Quint W, Zijlstra M, Maandag ER, Boelens $\mathrm{W}$, et al. Murine leukemia virus-induced T-cell lymphomagenesis: integration of proviruses in a distinct chromosomal region. Cell 1984; 37: 141-50.

7 Eichmann A, Yuan L, Breant C, Alitalo K, Koskinen PJ. Developmental expression of Pim kinases suggests functions also outside of the hematopoietic system. Oncogene 2000; 19: 1215-24.

8 van der Lugt NM, Domen J, Verhoeven E, Linders K, van der Gulden H, Allen J. Proviral tagging in E mu-myc transgenic mice lacking the Pim-1 proto-oncogene leads to compensatory activation of Pim-2. EMBO J 1995; 14: 2536-44.

9 Allen JD, Verhoeven E, Domen J, vanderValk M, Berns A. Pim-2 transgene induces lymphoid tumors, exhibiting potent synergy with c-myc. Oncogene 1997; 15: 1133-41.

10 Saris CJ, Domen J, Berns A. The Pim-1 oncogene encodes two related protein-serine/threonine kinases by alternative initiation at AUG and CUG. EMBO J 1991; 10: 655-64.

11 Yan B, Zemskova, Holder S, Chin V, Kraft A. The PIM-2 kinase phosphorylates BAD on seine 112 and reverses BAD-induced cell death. J Biol Chem 2003; 46: 45358-67.

12 Chalk AM, Sonnhammer EL. Computational antisense oligo prediction with a neural network model. Bioinformatics 2002; 18: $1567-75$.

13 Shao RG, Cao CX, Shimizu T, O’Connor PM, Kohn KW, Pommier Y. Abrogation of an S-phase checkpoint and potentiation of camptothecin cytotoxicity by 7-hydroxystaurosporine ( $\mathrm{UCN}-01)$ in human cancer cell lines, possibly influenced by p53 function. Cancer Res 1997; 57: 4029-35.

14 Wang Z, Bhattacharya N, Mixter PF, Wei W, Sedivy J, Magnuson NS. Phosphorylation of the cell cycle inhibitor $\mathrm{p} 21 \mathrm{Cip} 1 / \mathrm{WAF} 1$ by Pim-1 kinase. Biochim Biophys Acta 2002; 1593: 45-55.

15 Yang SP, Song ST, Tang ZM, Song HF. Optimization of antisense drug design against conservative local motif in simulant secondary structures of HER-2 mRNA and QSAR analysis. Acta Pharmacol Sin 2003; 24: 897-902.

16 Zheng SX, Zhou LJ, Zhu XZ, Jin YX. Antisense oligodeoxynucleotide inhibits vascular endothelial growth factor in human glioma cells. Acta Pharmacol Sin 2000; 21: 211-4.

17 Sun HZ, Wu SF, Tu ZH. Knockdown of IGF-IR by antisense oligodeoxynucleotide auguments the sensitivity of bladder cancer cells to mitomycin. Acta Pharmacol Sin 2001; 22: 841-6.

18 Lahn M, Sundell K, Moore S. Targeting protein kinase C-alpha (PKC-alpha) in cancer with the phosphorothioate antisense oligonucleotide aprinocarsen. Ann NY Acad Sci 2003; 1002: 263-70.

19 Datta SR, Ranger AM, Lin MZ, Sturgill JF, Ma YC, Cowan CW, et al. Survival factor-mediated BAD phosphorylation raises the mitochondrial threshold for apoptosis. Dev Cell 2002; 3: 631-43.

20 Plas DR, Thompson CB. Cell metabolism in the regulation of programmed cell death. Trends Endo Met 2002; 13: 74-8. 